\title{
Sellar Embryonal Carcinoma
}

National Cancer Institute

\section{Source}

National Cancer Institute. Sellar Embryonal Carcinoma. NCI Thesaurus. Code C155805.

An embryonal carcinoma that arises from or adjacent to the sellar region. 